\title{
Descarte de lixiviado de aterros sanitários em estações de tratamento de esgoto: uma análise crítica
}

\author{
Disposal Of Landfill Leachate In Wastewater Treatment Plants: A \\ Critical Analysis
}

\author{
José Roberto Campos*
}

Data de entrada: 21/03/2014 | Data de aprovação: 21/05/2014

DOI: http://dx.doi.org/10.4322/DAE.2014.129

\section{Resumo}

A quase totalidade dos projetos de Estações de Tratamento de Esgoto (ETEs) é concebida sem a previsão para receber lodos oriundos de fossas/tanques sépticos e de lixiviado de aterro sanitário. Porém, depois de construídas, em muitos casos, essas ETEs - por motivos diversos - passam a se prestar para o descarte dos resíduos citados.

Em estudos e pareceres que autorizam a recepção desses resíduos, a decisão geralmente fundamenta-se apenas em ponderações baseadas em variáveis como DBO, DQO, Nitrogênio e, também na sobrecarga provável em termos de taxas de carregamento orgânico e geração adicional de lodo.

Neste artigo, o autor, baseado em sua experiência pessoal e em resultados de diversas pesquisas sobre lixiviado produzidas por participantes do programa PROSAB (FINEP - Financiadora de Estudos e Projetos, CNPq, CEF e ABES - 2009), apresenta uma análise crítica sobre o tema que foi abordado em livro coordenado por Gomes, L.P. (2009). Também são usadas fundamentações baseadas em artigos de outras fontes para a estruturação das críticas enfocadas.

Parcela significativa dos componentes do lixiviado não é tratada (removida/degradada/convertida) em ETEs e, assim, critérios usuais de análise de impactos (na ETE e no corpo receptor) fundamentados apenas nas variáveis DBO, DQO e Nitrogênio não oferecem segurança. Sempre há elevação da carga no efluente da ETE e, além disso, certamente, compostos resistentes ao tratamento são descartados no corpo receptor. Conclui-se que os critérios de avaliação da problemática e os tipos de análises químicas de monitoramento têm de ser aperfeiçoados para que se possa, realmente, determinar os danos na própria ETE e também, no corpo receptor e na qualidade e quantidade do lodo gerado.

Modelos da cinética da degradação de lixiviado - quando descartado em reatores biológicos projetados para tratar somente esgoto sanitário - têm de ser aprimorados, pois a maioria deles apoia-se apenas em parâmetros como DQO e Nitrogênio.

Descartar lixiviado de aterros sanitários em ETEs não é sinônimo de tratar esses resíduos e há de se avaliar os danos reais decorrentes desse ato. 


\section{Introdução}

A Lei 12.305/10, em vigor no Brasil desde 2010, que estruturou a Política Nacional de Resíduos Sólidos - regulamentada pelo Decreto 7.404/10 - impõe que até agosto de 2014, todo o resíduo sólido gerado no país deverá ter seu destino técnica e ambientalmente correto.

Isso implica, naturalmente, que haverá a necessidade de se implantar e operar, de forma responsável, muitos novos aterros sanitários no país; sendo que os resíduos recicláveis não deverão ser descartados nessas instalações.

Face ao cenário atual, o prazo-limite estabelecido não será cumprido por todos os municípios brasileiros, porém a edição da referida Lei constitui passo decisivo para a regularização, gerenciamento e regulação de resíduos sólidos no país. É evidente, que, mesmo considerando-se o aproveitamento da parcela reciclável, esses aterros sanitários gerarão expressiva quantidade de lixiviado.

Há diferentes alternativas para destino e tratamento desse lixiviado, porém uma delas recai no descarte desse resíduo em estações de tratamento de esgoto. Há opiniões controversas sobre essa alternativa. Alguns consideram que ela é aplicável e efetiva quando a relação entre vazão e carga de lixiviado é pequena em relação a vazão e carga do esgoto sanitário (até $2 \%$, por exemplo) tratado na ETE; e, outros, posicionam-se reticentes, fundamentados nos danos potenciais aos processos e operações que constituem a ETE, e que, o sistema de tratamento para esgoto sanitário não é totalmente efetivo para tratar todos os componentes do lixiviado.

Infelizmente, constata-se que há muitas ETEs no Brasil recebendo esse tipo de resíduo sem que haja a preocupação necessária com a problemática envolvida. De maneira geral, essas ETEs não foram projetadas para receber e tratar (adicionalmente) o lixiviado nelas descartado. Quase sempre o lançamento passa a ser efetuado depois de a ETE estar construída e em operação de rotina. Em muitos casos, não há nem mesmo o conhecimento do projetista sobre essa sobrecarga desconsiderada na concepção do sistema.

Neste artigo é efetuada uma abordagem geral sobre essa problemática com base nos critérios mais comuns utilizados para avalizar essa prática (descarte de lixiviado de aterro sanitário em ETEs). É apresentada uma análise crítica sobre as consequências potenciais e é questionada a efeti- vidade da adoção dessa prática.

\section{Lixiviados de Aterros}

A literatura técnica é farta de resultados de pesquisas direcionadas à caracterização qualitativa e quantitativa de lixiviados de aterros, e, também, sobre alternativas para seu tratamento.

É fato notório que a variabilidade das características físico-químicas e de quantidade é impressionante, pois depende da composição do resíduo sólido, configuração e controle do aterro, idade do aterro, temperatura, precipitação pluviométrica, critérios de operação do aterro, etc.

Talvez um dos principais fatores recaia na idade do aterro, pois a DQO média do lixiviado pode variar, preponderantemente, na faixa de 1.000 $\mathrm{mg} \cdot \ell^{-1}$ (aterro "velho") a $60.000 \mathrm{mg} \cdot \ell^{-1}$ (aterro "jovem"); assim como é observada a grande variação da concentração de outros componentes, tais como metais, substâncias húmicas, etc. Face a isso, ao se levantar material bibliográfico sobre a composição de lixiviado e seu tratamento encontram-se grandes disparidades nas conclusões de diferentes autores.

Segundo Lange, C.L. e Amaral, M.C.S (2009), para aterros jovens a relação DBO/DQO varia entre 0,5 a 0,8 , ao passo que para aterros antigos a variação dessa relação pode-se enquadrar na faixa de 0,04 a 0,08.

Como as características mudam ao longo da idade do aterro, também as soluções para tratamento variam de forma considerável. Um sistema para tratamento de lixiviado de aterro jovem pode não atender aos quesitos essenciais para o tratamento de um aterro com vários anos de operação.

O quê se pretende enfocar neste texto recai principalmente no fator desconhecido pertinente aos componentes que não são detectados pelas análises de rotina de monitoramento de ETEs e que não se manifestam em resultados de DQO, ou nem mesmo são mensurados.

Na determinação da DBO para águas residuárias que contêm substâncias tóxicas é necessária a utilização de inóculo contendo micro-organismos previamente adaptados ao substrato a ser avaliado. Essa precaução nem sempre é tomada por aqueles que efetuam análises de lixiviados e de misturas de lixiviado e esgoto. Isso faz com que os valores obtidos nessas determinações resultem inferiores àqueles que mais se aproximam da realidade. 
A DQO somente detecta a demanda de oxigênio de componentes susceptíveis às reações dos componentes, provocadas pelos oxidantes fortes usados nos métodos-padrão de laboratório. Há diversos compostos que não são corretamente avaliados nessa análise, incluindo benzeno, tolueno, piridina e compostos alifáticos e hidrocarbonetos aromáticos, em geral. Portanto, é provável que a análise de DQO, embora essencial para monitoramento da qualidade de lixiviados, pode apresentar erro considerável.

Há de se reconhecer que ao se estimar a DQO de um efluente, é disponibilizado um dado muito importante, contudo, a DQO apresenta fragilidades relacionadas com o conhecimento do quê causa essa DQO. Mesmo para esgoto sanitário, em análises de DQO do efluente tratado, ainda restam questionamentos.

Aquino (2003) elaborou análise crítica sobre a caracterização da DQO de efluentes de ETEs tratando esgoto sanitário. Mesmo considerando que não se incluíam descartes de lixiviado nessas ETEs, o autor levanta amplo e preciso questionamento sobre o quê constitui a mistura de compostos que efetivamente causam essa DQO. Evidentemente quando existem descargas de efluentes mais complexos - na entrada da ETE - mais problemática se transforma a tarefa de se efetuar essa caracterização, pois, nesse cenário, pode ocorrer a presença de compostos não "mensuráveis" pelo método de análise da DQO. Algumas observações do referido autor, são destacadas a seguir:

"A matéria orgânica efluente de sistemas de tratamento, expressa como DQO, é frequentemente dita como residual. Embora não haja nenhum método de se medir a "residualidade" de uma amostra, a DQO é comumente associada à lenta biodegradabilidade. O termo "residualidade" não se refere apenas à biodegradabilidade de uma substância, mas também, às limitações do processo de tratamento como um todo, em reter aquela substância em questão".

"A DQO residual dissolvida e efluente de sistemas de tratamento biológico consiste de vários compostos orgânicos que podem incluir: substrato residual degradável; compostos "recalcitrantes" presentes no efluente que passam incólumes pelo sistema de tratamento; compostos intermediários e produtos microbianos solúveis".

O autor cita a importância do uso de técnicas avançadas de análise química para o efluente tratado, a caracterização química por cromatografia a gás, acoplada a espectrometria de massa (CG-MS), ressonância magnética nuclear (NMR-H), extração líquido-líquido seguida de CG-MS, etc.

$\mathrm{O}$ autor enfoca a importância de se conhecer a distribuição da massa molecular dos componentes do efluente mediante o emprego de ultrafiltração em membranas (distribuição discreta) e da cromatografia em gel (distribuição contínua).

$\mathrm{O}$ autor também sugere testes de toxicidade e cita diversos pesquisadores que consistentemente concluem que "a toxicidade dos efluentes secundários, pode ser maior do que a toxicidade do afluente ao sistema". "Os compostos microbianos formados durante o tratamento biológico podem ser mais tóxicos que os compostos originariamente presentes na água residuária a ser tratada".

"A maioria dos estudos de caracterização de DQO "residual" não discrimina compostos produzidos pelo sistema de tratamento a partir dos compostos originariamente presentes no afluente, e mostra que, embora a DQO "residual" seja biodegradável aeróbia e anaerobiamente, ela pode ser considerada "inerte" para os tempos de detenção hidráulica comumente usados”.

Lange et al (2009) destacam que "várias classes de compostos orgânicos têm sido identificadas nos lixiviados, que podem ser classificadas em três grupos: ácidos graxos de baixa massa molecular, substâncias húmicas de massa molecular intermediária e substâncias fúlvicas de massa molecular intermediária. Resultados obtidos pelos autores citados resultam de pesquisa empregando não somente as análises de rotina, mas métodos mais sofisticados, incluindo cromatografia gasosa acoplada a espectrometria de massa.

Lange et al (2009) determinaram a fração representada pela DQO "inerte" de amostras provenientes da mistura de lixiviado de aterros com 20; 10 e 6 anos de operação. Foram estudados cenários com condições anaeróbia e aeróbia. Segundo os autores, a fração de DQO "inerte" passa pelo tratamento biológico "inalterada", mascarando o resultado de tratabilidade biológica.

As frações determinadas para a DQO "inerte" (em relação à DQO inicial) resultaram em 44\% e $42 \%$, para metabolismo aeróbio e anaeróbio, respectivamente. Ainda segundo Lange et al (2009) "Tais resultados sugerem que lixiviados com es- 
sas características demandam sistemas de tratamento que conjuguem processos físico-químicos, atuando como pré ou pós tratamento de processos biológicos".

Esses autores detectaram a presença de compostos constituintes que provavelmente são resistentes à degradação biológica (ou recalcitrantes), tais como: "2-[2-propenil] ciclohexanona, bis[2-metilpropil] éster de 1,2-ácido benzeno dicarboxílico, 2-etil ácido hexanóico, 4,4-[1-metiletilidene] bis-fenol, 1-metil, 4-[1 metil etil] 1,2-ciclohexanodiol, 4-hidroxi- $\alpha, \alpha$, 4-trimetil ciclo hexano metanol, cânfora, ácido primárico, hidroximetil dihidrofuran - 2-ona e outros. Também concluíram que nos aterros com maior tempo de operação (20 a 10 anos) houve predomínio de contaminantes com menor massa molecular $(<1 \mathrm{kDa})$, que provavelmente podem ser mais facilmente biodegradados - embora também tenha sido detectada fração significativa de componentes com alta massa molecular (> $100 \mathrm{kDa})$.

Yunus et al (2011), empregando técnicas de análise de lixiviados por meio de absorção de radiação ultravioleta e espectroscopia (fluorescência), investigaram a geração de compostos orgânicos recalcitrantes e sua presença em lixiviados decorrentes da degradação anaeróbia de resíduos sólidos urbanos. Foram empregados dois tipos de amostragem; uma delas constituída de resíduos logo após a sua coleta, e outra, que foi preparada mantendo-a, previamente, sob co-compostagem (com cerca de 36,51\% de grama) em ambiente aeróbio, durante 42 dias.

Essas amostras receberam a adição de solução de macronutrientes e de inóculo $(10 \%$ em volume) constituído de lodo proveniente de digestor anaeróbio de estação de tratamento de esgoto. Foram feitas análises da composição de amostras com base em determinações de concentração de celulose, hemicelulose e lignina. Para o percolado também foram feitas análises de COD (Carbono Orgânico Dissolvido) e de estruturas aromáticas dissolvidas.

Para a amostra de resíduos frescos, após 150 dias de digestão, houve degradação de 56,0\% de celulose, $8,8 \%$ de hemicelulose e de $18,0 \%$ de lignina, e, para a amostra preparada,43,0\%; 22,0\% e de $1,4 \%$, respectivamente (referência: massa seca).

Análises do lixiviado demonstraram que a concentração de compostos aromáticos cresceu com a degradação dos resíduos ao longo do período de acompanhamento. Também foi detectada a presença acentuada de substâncias húmicas e fúlvicas. Os autores concluíram que a evolução de compostos orgânicos recalcitrantes, durante o processo de biodegradação, pode ser atribuída a decomposição de celulose e de produtos advindos da síntese microbiana.

YUNUS et al 2011, apresentam uma síntese de considerações (enumeradas a seguir) sobre lixiviado de aterros (com base em suas conclusões e de outros pesquisadores.

Os lixiviados contêm compostos orgânicos biodegradáveis de baixa massa molecular (carboidratos, aminoácidos, ácidos orgânicos, etc) e compostos orgânicos com elevada massa molecular, não facilmente biodegradáveis - a maior parte constituída de ácidos húmicos e fúlvicos, que representam diferentes compostos aromáticos, alifáticos e fenólicos.

Esses compostos e outras substâncias potencialmente tóxicas constituem parcela que é muito resistente à degradação por micro-organismos.

Esses compostos podem "atravessar" o sistema de tratamento biológico de ETEs sem sofrer modificações (YUNUS-2011, apud OZKAYA et al, 1998) e estar presentes no efluente do tratamento

As variáveis mais comumente utilizadas para caracterizar os lixiviados e seus sistemas de tratamento, são a DBO (Demanda Bioquímica de Oxigênio e COT (Carbono Orgânico Total). Essas variáveis apenas permitem detectar a quantidade residual de compostos orgânicos, porém não possibilitam a distinção exata da matéria orgânica "biodegradável" e da "recalcitrante". Segundo Yunus et al (2009), encontram-se na literatura citações de análises/ensaios, não padronizados, tais como: DQO “inerte”, biodegradabilidade aeróbia e distribuição de massa molecular.

Destaque especial merecem as substâncias húmicas que, de maneira geral, apresentem caráter coloidal (quando a massa molecular é elevada) e possuem sistemas com cargas, que podem reter outros contaminantes, inclusive metais. Em águas naturais diversos pesquisadores concluíram que há correlação entre a concentração das substâncias húmicas e a dosagem necessária de coagulante (quando se deseja sua remoção por coagulação/floculação). As substâncias húmicas são geradas em processos de decomposição de matéria orgânica e sua estrutura depende do 
tipo de substrato e dos micro-organismos responsáveis por sua decomposição. Face a isso podem possuir composições muito distintas. Essa diferenciação influencia nas reações químicas das mesmas - em meio aquoso - , que dependem dentre outros fatores, do caráter aromático ou alifático das moléculas húmicas envolvidas (COSTA, C.A. 1992). Sem dúvida essas características relacionam-se com as dificuldades para remoção via coagulação/flotação e por processos biológicos.

Boccheglieri, M.M. (2010) discutiu os efeitos do recebimento de lixiviado em quatro estações de tratamento de esgoto em operação no Estado de São Paulo (Brasil): lodos ativados convencional e por bateladas, lagoa anaeróbia seguida por lagoa facultativa e lagoas aeradas. Embora tenha se posicionado, no geral, que o "tratamento conjunto de lixiviado de aterro é uma alternativa a ser considerada no planejamento dos sistemas de resíduos sólidos e de esgoto sanitário", a pesquisadora destaca vários aspectos negativos que devem ser levados em consideração; entre os quais: "O recebimento de lixiviado para tratamento conjunto com esgotos sanitários é adotado em vários países, porém, ainda são necessários estudos para a compreensão integral das implicações deste procedimento em relação a diversos aspectos tais como os efeitos tóxicos aos processos biológicos, qualidade do lodo e do efluente do tratamento....

\section{Resultados de pesquisas desenvolvidas no PROSAB-FINEP-ABES}

Em 2009 foi publicado o livro RESÍDUOS SÓLIDOS: ESTUDO DE CARACTERIZAÇÃO E TRATABILIDADE DE LIXIVIADOS DE ATERROS SANITÁRIOS PARA AS CONDIÇÕES BRASILEIRAS, coordenado por GOMES, L. P., em que houve a participação de diversos grupos de pesquisa, de reconhecida capacidade, enfocando o tratamento de lixiviado de aterros e, também, o tratamento em conjunto de lixiviado com esgoto sanitário em ETEs de diferentes configurações. Trata-se de importante documento que envolve diferentes resultados e opiniões.

$\mathrm{O}$ autor do presente texto usou-se desses resultados, para elaborar a base deste artigo; e, além disso, incluiu sua experiência pessoal e resultados de outras pesquisas citadas no texto.

Para consolidar esta análise, a quase totalidade das pesquisas que constam do referido livro é apresentada na forma de resumo elaborado pelo autor deste texto crítico.

No Quadro 1 são destacados estudos e seus resultados referentes ao tema do tratamento específico de lixiviados, e no Quadro 2, aqueles referentes ao descarte de lixiviado em ETEs, para avaliar o provável tratamento em conjunto.

Como era esperado, face à diversidade de cenários em que foram desenvolvidos os trabalhos, pode-se notar resultados discrepantes entre as pesquisas. Isso é perfeitamente compreensível, pois nesta compilação têm-se pesquisas em escala de bancada, piloto e plena; além disso, diferentes lixiviados e composição do esgoto, e, ainda, distintas concepções e critérios de análise.

Uma análise objetiva dos resultados das pesquisas enumeradas no Quadro 1, permite destacar:

O lixiviado, quando tratado em lagoas (aeradas ou não) exige tempo de detenção hidráulica (TDH) bastante elevado. Com TDH de 56 dias (sem aeração), a remoção de DQO foi de 80\%.

Em filtros anaeróbios, com TDH médio de cerca de 10 dias, a eficiência de remoção de DQO alcançou valores próximos a 66\%.

Em reator anaeróbio, com agitação mecânica e temperatura controlada $\left(30 \pm 2^{\circ} \mathrm{C}\right)$ com ciclos de 24 horas, a remoção de DQO bruta resultou em $\left.(68 \pm 15) \mathrm{mg}^{-1}\right)$.

Pode-se alcançar a nitrificação/desnitrificação do lixiviado com TDH superior a 10 dias de aeração, porém a remoção de DQO é muito baixa, e, há necessidade de adição de fonte exógena de carbono quando se deseja a desnitrificação (e pode haver demanda de alcalinizante para a nitrificação).

Empregando-se reator anaeróbio compartimentado pode-se alcançar remoção de DQO superior a $97 \%$ para TDH de 80 dias, e $80 \%$ para TDH de 5 dias. Para TDH de 30 dias, a eficiência foi da ordem de $90 \%$.

Note-se que, com exceção do caso em que se usou reator operado em bateladas (Quadro 1) sob condições controladas (temperatura e agitação) em escala de laboratório, fica evidente que não foi alcançada "razoável" remoção de DQO sem que o TDH fosse da ordem de vários dias. Ressalte-se que em nenhuma das pesquisas citadas estudou-se os componentes que causam a DQO residual no efluente do sistema estudado - apenas foram determinadas variáveis que se usam comumente para monitorar esgoto sanitá- 


\begin{tabular}{|c|c|c|c|}
\hline $\begin{array}{l}\text { Autores/ } \\
\text { Equipe }\end{array}$ & Objetivo da Pesquisa & Experimento & Principais Conclusões \\
\hline $\begin{array}{l}\text { CASTILHOS, } \\
\text { A.B. et al } \\
\text { (2009) Univer- } \\
\text { sidade Federal } \\
\text { de Santa } \\
\text { Catarina }\end{array}$ & $\begin{array}{l}\text { Tratamento de } \\
\text { lixiviado em sistemas } \\
\text { de lagoas (anaeróbia e } \\
\text { facultativa). }\end{array}$ & $\begin{array}{l}\text { O sistema experimental foi operado com duas } \\
\text { linhas, uma delas com lagoa anaeróbia seguida por } \\
\text { lagoa facultativa (TDH total: } 56 \text { dias), e, outra, } \\
\text { com lagoa anaeróbia seguida por duas lagoas } \\
\text { facultativas em série (TDH total: } 98 \text { dias). A DQO e } \\
\text { a DBO média do lixiviado na primeira etapa foram, } \\
\text { respectivamente: ( } 3.650+663) \mathrm{mg} / \ell \text { e }(1.194 \pm \\
275) \mathrm{mg \ell} \text {, e, na segunda etapa: }(3.287 \pm 704) \text { e } \\
(1300 \pm 623) \text { mgl. }\end{array}$ & $\begin{array}{l}\text { Remoção média de DQO e de DBO foi de } 60 \text { e } 80 \% \text {, } \\
\text { respectivamente. Contudo o valor da DBO do efluen- } \\
\text { te resultou em cerca de apenas } 20 \text { a } 33 \% \text { do valor } \\
\text { da DQO, "evidenciando a degradação da matéria } \\
\text { orgânica biodegradável e a permanência no sistema } \\
\text { da matéria refratária". A cor foi pouco removida: } \\
\text { eficiência média entre } 22 \text { e } 53 \% \text {. Houve redução de } \\
\text { toxicidade entre 59\% e } 94 \% \text {. }\end{array}$ \\
\hline $\begin{array}{l}\text { CASTILHOS, } \\
\text { A.B. et al } \\
\text { (2009) Univer- } \\
\text { sidade Federal } \\
\text { de Minas Gerais }\end{array}$ & $\begin{array}{l}\text { Tratamento de } \\
\text { lixiviado em lagoa } \\
\text { facultativa e lagoa } \\
\text { aerada. }\end{array}$ & $\begin{array}{l}\text { O sistema experimental foi operado abrangendo } \\
\text { as alternativas: } \mathrm{i} \text { ) lagoas facultativas (TDH: } 7 \text { e } \\
14 \text { dias) e aerada (TDH: } 7 \text { dias). A DQO solúvel do } \\
\text { lixiviado prevaleceu na faixa de } 1500 \mathrm{mg}^{-1} \text { a } 3500 \\
\mathrm{mg}^{-1} \text {. }\end{array}$ & $\begin{array}{l}\text { Não houve êxito para o tratamento nas lagoas facul- } \\
\text { tativas. A lagoa aerada alcançou “equilíbrio” depois } \\
\text { do } 560 \text { dia de operação; neste caso a remoção de } \\
\text { DQO solúvel foi de apenas } 20 \% \text {. }\end{array}$ \\
\hline $\begin{array}{l}\text { CASTILHOS A.B. } \\
\text { et al (2009) } \\
\text { Universidade } \\
\text { Federal de } \\
\text { Lavras }\end{array}$ & $\begin{array}{l}\text { Tratamento de } \\
\text { lixiviado em sistemas } \\
\text { com lagoa aerada e } \\
\text { decantador; com e } \\
\text { sem a realização de } \\
\text { stripping de amônia } \\
\text { (à montante do trata- } \\
\text { mento). }\end{array}$ & $\begin{array}{l}\text { Os componentes dos sistemas operacionais foram: } \\
\text { i) lagoa de stripping (TDH: } 20 \text { dias), lagoa aerada } \\
\text { (TDH: } 5 \text { dias) e decantador (TDH: } 2 \text { dias), e, ii) } \\
\text { lagoa aerada (TDH: } 5 \text { dias) e decantador (TDH: } \\
2 \text { dias). O valor da DQO do lixiviado variou entre } \\
2.430 \text { a } 3.057 \mathrm{mg \ell}^{-1} . \text { A DBO média do afluente foi } \\
\text { de } 162 \mathrm{mg \ell}^{-1} \text {. }\end{array}$ & $\begin{array}{l}\text { A remoção média de DQO e de DBO foi de, res- } \\
\text { pectivamente } 33 \% \text { e } 46 \% \text { no sistema com stripping } \\
\text { prévio, e, no outro, de } 12 \% \text { e } 51 \% \text {. “A biomassa não } \\
\text { se desenvolveu satisfatoriamente (com baixos valores } \\
\text { de SSV } 180 \mathrm{mg}^{-1} \text { )". }\end{array}$ \\
\hline $\begin{array}{l}\text { GOMES, L.P. } \\
\text { et al (2009) } \\
\text { UNISINOS }\end{array}$ & $\begin{array}{l}\text { Tratamento de } \\
\text { lixiviado em filtros } \\
\text { anaeróbios. }\end{array}$ & $\begin{array}{l}\text { Foram estudadas quatro unidades de filtros } \\
\text { anaeróbios, dois deles com recheio de brita no } 5 \text { e } \\
\text { dois, com blocos de concreto. Foram testados fluxo } \\
\text { ascendente e descendente; e a relação DBO/DQO } \\
\text { do substrato variou entre } 0,28 \text { e } 0,59 \text {. O TDH médio } \\
\text { adotado foi de } 10,8 \text { e } 7,4 \text { dias. A DQO média do } \\
\text { afluente resultou da ordem de } 6150 \mathrm{mgl}^{-1} \text {. }\end{array}$ & $\begin{array}{l}\text { “Após } 540 \text { dias de operação a eficiência média de } \\
\text { remoção de DQO, em cada reator, foi de } 65 \% \text {; } 66 \% \text {; } \\
67 \% \text { e } 66 \% \text { ". }\end{array}$ \\
\hline $\begin{array}{l}\text { GOMES, L.P. } \\
\text { et al (2009) } \\
\text { Universidade } \\
\text { Federal de } \\
\text { Minas Gerais }\end{array}$ & $\begin{array}{l}\text { Tratamento de } \\
\text { lixiviado em filtros } \\
\text { anaeróbios associados } \\
\text { a lagoa de polimento. }\end{array}$ & $\begin{array}{l}\text { Foram testadas configurações de filtro anaeró- } \\
\text { bio seguido por lagoa, e, lagoa seguida de filtro } \\
\text { anaeróbio. O TDH médio nos filtros foi de } 1,45 \text { dia, } \\
\text { e, nas lagoas } 3,79 \text { dias e } 6,36 \text { dias. Além disso, } \\
\text { foram testados substratos brutos e substratos } \\
\text { acrescidos de nutrientes. A DQO do afluente variou, } \\
\text { preponderantemente, na faixa de } 2000 \text { e } 3000 \\
\text { mg } \ell^{-1} \text {. }\end{array}$ & $\begin{array}{l}\text { “Os filtros não apresentaram sinais das premissas } \\
\text { estabelecidas para o sucesso da partida dos mesmos, } \\
\text { indicando, provavelmente, a não viabilidade desse } \\
\text { tipo de sistema de tratamento para lixiviados com } \\
\text { características refratárias semelhantes ao emprega- } \\
\text { do nesta pesquisa”. }\end{array}$ \\
\hline $\begin{array}{l}\text { GOMES, L.P. } \\
\text { et al (2009) } \\
\text { Universidade } \\
\text { de Brasília }\end{array}$ & $\begin{array}{l}\text { Tratamento do } \\
\text { lixiviado em reator } \\
\text { anaeróbio opera- } \\
\text { do com bateladas } \\
\text { sequenciais. }\end{array}$ & $\begin{array}{l}\text { O reator foi operado com ciclos de } 24 \text { horas, } \\
\text { sendo que } 23 \text { horas foram destinadas para ação do } \\
\text { processo anaeróbio, e } 1 \text { hora para sedimentação. } \\
\text { Na fase de reação foi aplicada agitação mecânica. } \\
\text { O reator foi mantido a }(30 \pm 1)^{\circ} \mathrm{C} \text {. A DQO média do } \\
\text { lixiviado foi de } 227 \mathrm{mg}^{-1} \text { e a taxa de carregamento } \\
\text { orgânico média foi de } 1,14 \mathrm{~kg} \mathrm{DQO} \mathrm{m}^{-3} \text { dia }^{-1}\end{array}$ & $\begin{array}{l}\text { “O sistema anaeróbio apresentou eficiência de } \\
\text { remoção ou DQO para amostras brutas e filtradas, de } \\
(68 \pm 15) \% \text { e }(76 \pm 11) \% \text {, respectivamente. A vazão de } \\
\text { produção de metano variou na faixa de } 0,7 \text { a } 3,8 \ell \\
\text { CH4(gDQO })^{-1} \text {. }\end{array}$ \\
\hline $\begin{array}{l}\text { LOPES D.D et al } \\
\text { (2009) Univer- } \\
\text { sidade Estadual } \\
\text { de Lavras }\end{array}$ & \begin{tabular}{l|} 
Nitrificação e desni- \\
trifi-cação de lixiviado \\
em reator anóxico \\
seguido por reator \\
aeróbio (e decanta- \\
-dor), com e sem \\
recircula-ção interna. \\
Também foi testado o \\
uso de fonte exógena \\
de carbono.
\end{tabular} & $\begin{array}{l}\text { O TDH médio no sistema foi variado entre } 13 \text { e } 20 \\
\text { dias. Foi necessária a adição de alcalinizante para } \\
\text { viabilizar a nitrificação. }\end{array}$ & $\begin{array}{l}\text { A remoção de nitrogênio amoniacal, na maior parte } \\
\text { do tempo, manteve-se próxima a } 98 \% \text {; contudo, a } \\
\text { remoção de DQO variou entre } 15 \% \text { e } 49 \% \text {. }\end{array}$ \\
\hline $\begin{array}{l}\text { LOPES, D.D. } \\
\text { et al (2009) } \\
\text { Universidade } \\
\text { Estadual de } \\
\text { Lavras }\end{array}$ & $\begin{array}{l}\text { Remoção de nitrogê- } \\
\text { nio, via nitrito, em } \\
\text { sistema ali-mentado } \\
\text { intermitentemente }\end{array}$ & $\begin{array}{l}\text { Foram avaliados desempenhos para diversos valo- } \\
\text { res de TDH: aeração: } 6 \text { a } 10 \text { dias, e, fase anóxica: } \\
33 \text { a } 66 \text { horas. }\end{array}$ & $\begin{array}{l}\text { Constatou-se, na fase aeróbia, a oxidação de pratica- } \\
\text { mente todo o N-Amoniacal. A remoção de DQO variou } \\
\text { na faixa de } 6 \text { a } 15 \% \text {. Na fase anóxica a desnitritação } \\
\text { e desnitratação completas apenas ocorreram com a } \\
\text { adição de etanol. }\end{array}$ \\
\hline $\begin{array}{l}\text { LOPES, D.D. } \\
\text { et al (2009) } \\
\text { Universidade } \\
\text { de Brasília }\end{array}$ & $\begin{array}{l}\text { Remoção de nitrogê- } \\
\text { nio em sistema ope- } \\
\text { rado em reator com } \\
\text { bateladas sequenciais. }\end{array}$ & $\begin{array}{l}\text { O reator foi operado em ciclos de } 48 \text { horas ( } 24 \\
\text { horas com aeração, } 23 \text { horas sem aeração e } 1 \text { hora } \\
\text { para sedimentação), na maior parte da pesquisa } \\
\text { não foi necessário o uso de alcalinizante, porém, } \\
\text { o uso de fonte exógena de carbono (etanol) foi } \\
\text { obrigatório. O valor médio de DQO do lixiviado foi } \\
\text { de } 2.938 \mathrm{mg}^{-1} \text {, e de NTK, } 1.739 \mathrm{mg}^{-1} \text {. }\end{array}$ & $\begin{array}{l}\text { No texto não há referência sobre a remoção de DQO. } \\
\text { Os resultados obtidos para conversão de N-amoniacal } \\
\text { a nitrito e nitratos variaram na faixa de } 54 \% \text { a } 99 \% \text {. } \\
\text { "Eficiências de remoção de nitrogênio de } 80 \% \text { foram } \\
\text { comuns durante o monitoramento". Concluiu-se, } \\
\text { também, que o período destinado à oxidação não foi } \\
\text { suficiente. }\end{array}$ \\
\hline $\begin{array}{l}\text { CLARETO, C.R. } \\
\text { (1997) Univer- } \\
\text { sidade de São } \\
\text { Paulo - Escola } \\
\text { de Engenharia } \\
\text { de São Carlos* }\end{array}$ & $\begin{array}{l}\text { Degradação anaeróbia } \\
\text { de lixiviado em reator } \\
\text { anae-róbio comparti- } \\
\text { mentado. }\end{array}$ & $\begin{array}{l}\text { Foi estudado reator anaeróbio compartimenta-do } \\
(4 \text { câmaras em série), , operado na temperatura de } \\
(30 \pm 2)^{\circ} \mathrm{C} \text {, com TDH total de } 80 ; 45 ; 15 \text { e } 5 \text { dias. A } \\
\text { última câmara possuía recheio. Como se tratava } \\
\text { de aterro “jovem" a relação DBO/DQO, resultou } \\
\text { próximo a } 0,7\end{array}$ & 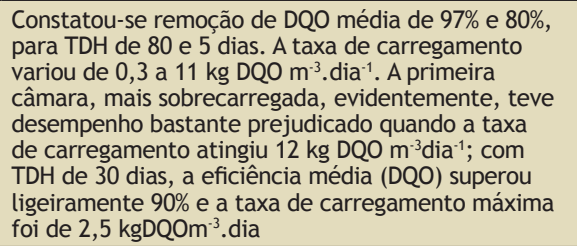 \\
\hline
\end{tabular}

QUADRO 1 - Resumo de conclusões de algumas pesquisas sobre tratamento específico de lixiviado (PROSAB 2009) 
rio.

Uma análise objetiva dos resultados das pesquisas enumeradas no Quadro 2, permite destacar:

O emprego de cloreto férrico em uma ETE, com tratamento primário quimicamente assistido, resultou em remoção média de DQO de 56\%. Em laboratório, empregando-se diferentes produtos obteve-se remoção na faixa de 33,6\% a 70,3\%.

No caso de uso de lodos ativados com alimentação contínua sob condições controladas (escala de bancada) foram encontrados bons resultados, porém, não confirmados em unidade em escala piloto. Neste caso, para TDH de 17 a 19 horas atingiram-se remoções de DQO na faixa de 60 a $77 \%$, porém houve formação de flocos com baixa sedimentabilidade.

Reatores UASB com TDH de 12 horas promo- veram remoção média de DQO de 55\% (relação lixiviado/esgoto: 1\%) e 45\% (relação lixiviado/ esgoto: 10\%). Ressalte-se que a eficiência de reatores UASB, tratando somente esgoto sanitário, em média, tem eficiência predominante na faixa de 65 a 75\%, com cerca de 8 horas de TDH.

Lagoa aerada seguida por lagoa de sedimentação (TDH na lagoa: 3,6 a 7,1 dias), sem adição de lixiviado, alcançou remoção de DQO de 82\%, porém quando foi descartado o lixiviado houve redução para 56 a 72\%. Lagoa facultativa seguida por lagoa de maturação (TDH: 6,1 a 15,2 dias), sem adição de lixiviado, apresentou remoção de DQO de 71\%, porém, quando aplicado o lixiviado, a remoção caiu para a faixa de $42 \%$ a $51 \%$.

Em síntese, a análise geral dos resultados expressa no Quadro 2 permite consolidar as conclusões, a seguir.

\begin{tabular}{|c|c|c|c|}
\hline $\begin{array}{l}\text { Autores/ } \\
\text { Equipe }\end{array}$ & Objetivo da Pesquisa & Experimento & Principais Conclusões \\
\hline $\begin{array}{l}\text { FERREIRA, } \\
\text { J.A. et } \\
\text { al (2009) } \\
\text { Universidade } \\
\text { Estadual } \\
\text { do Rio de } \\
\text { Janeiro }\end{array}$ & $\begin{array}{l}\text { Coagulação/floculação de } \\
\text { mistura de lixiviado e esgoto } \\
\text { sanitário. }\end{array}$ & $\begin{array}{l}\text { Foram realizados ensaios em jar-test. Produtos } \\
\text { testados: sulfato de alumínio, cloreto férrico, polí- } \\
\text { meros orgânicos (Tanfloc SG, Tanfloc SL - da Tanac, } \\
\text { Panfloc } \mathrm{L} \text { da Panamericana e polímero aniônico: } 0,5 \\
\text { e } 1,0 \mathrm{mg}^{-1} \text {. Para os coagulantes foram testadas as } \\
\text { dosagens de } 20 ; 40 \text { e } 60 \mathrm{mg}^{-1} \text {. Foram estudadas } \\
\text { relações lixiviado/esgoto, nas proporções: } 0,5 \% ; 2,0 \\
\text { e } 5,0 \% \text {. DQO média do esgoto: } 310 \mathrm{mg}^{-1} \text {; DQO média } \\
\text { do lixiviado: } 2.305 \mathrm{mg}^{-1} \text {. }\end{array}$ & $\begin{array}{l}\text { A remoção de DQO, para esgoto bruto, sem } \\
\text { adição de produtos químicos resultou infe- } \\
\text { rior a } 21 \% \text {. Com o emprego de coagulante, a } \\
\text { maior eficiência resultou em } 73,6 \% \text { ( } 20 \text { mg } \ell^{-1} \\
\text { de Panfloc). Para as relações de lixiviado/ } \\
\text { esgoto de } 20 \% \text { e de } 5,0 \% \text { a remoção variou } \\
\text { na faixa de } 33,6 \% \text { e } 54,3 \% \text { ( } 20 \text { mg } \ell^{-1} \text { Cloreto } \\
\text { Férrico). Para a relação de } 0,5 \% \text {, foram } \\
\text { alcançadas remoções de até } 65,2 \% \text { ( } 20 \text { mg } \ell^{-1} \\
\text { de Tanfloc) e } 70,3 \% \text { de (Panfloc). }\end{array}$ \\
\hline $\begin{array}{l}\text { FERREIRA, } \\
\text { J.A. et } \\
\text { al (2009) } \\
\text { Universidade } \\
\text { Estadual } \\
\text { do Rio de } \\
\text { Janeiro }\end{array}$ & $\begin{array}{l}\text { Avaliação, em ETE, de Niterói } \\
\text { (RJ), composta apenas por tra- } \\
\text { tamento primário (ETE Icaraí), } \\
\text { quimicamente assisti-do, e dos } \\
\text { impactos de lança-mento de } \\
\text { lixiviado de aterro sanitário. }\end{array}$ & $\begin{array}{l}\text { A ETE Icaraí possui gradeamento, desarenação, } \\
\text { tanque de mistura de coagulante (cloreto férrico), } \\
\text { decantação e secagem de lodo. Foram levantados } \\
\text { dados no ano de } 2007 \text { e parte de } 2008 \text {. A relação } \\
\text { lixiviado/esgoto (médias mensais) variou entre } \\
0,37 \% \text { e } 1,22 \% \text {, com média de } 0,68 \% \text {. O lixiviado é } \\
\text { descartado cerca de } 5 \text { km à montante da ETE e passa } \\
\text { por } 3 \text { elevatórias. }\end{array}$ & $\begin{array}{l}\text { A carga adicional de DQO decorrente do } \\
\text { descarte de lixiviado variou na faixa de } 1,3 \% \\
\text { a } 11,8 \% \text { e de N-Amoniacal, de } 69 \% \text { a } 70,5 \% ; \\
\text { e, a DQO do lixiviado, variou entre } 1428 \text { a } \\
1913 \text { mg } \ell^{-1} \text {. A remoção de DQO média foi de } \\
56 \% \text {. Foram feitos testes de toxicidade e os } \\
\text { autores concluíram que "é possível inferir } \\
\text { que o lixiviado é mais tóxico aos microcrus- } \\
\text { táceos avaliados do que o esgoto puro". }\end{array}$ \\
\hline $\begin{array}{l}\text { FERREIRA, } \\
\text { J.A. et } \\
\text { al (2009) } \\
\text { Universidade } \\
\text { Estadual } \\
\text { do Rio de } \\
\text { Janeiro }\end{array}$ & $\begin{array}{l}\text { Influência da mistura lixivia- } \\
\text { do/esgoto em siste-ma de } \\
\text { lodos ativados (escala de } \\
\text { bancada) }\end{array}$ & $\begin{array}{l}\text { Foi avaliado o processo de lodos ativados com } \\
\text { alimentação contínua (TDH: } 6 \text { horas) e com alimenta- } \\
\text { ção em bateladas (ciclo: } 24 \text { horas). Foram testadas } \\
\text { misturas de lixiviado, nas proporções de } 0,5 \text { a } 2,5 \% \text {, } \\
\text { em relação ao esgoto. Os valores de DQO das mistu- } \\
\text { ras variaram na faixa de } 381 \text { a } 330 \mathrm{mg}^{-1} \text { (para } 0,5 \text { e } \\
1,0 \% \text { ) e, de } 675 \text { a } 788 \mathrm{mg}^{-1} \text { (para } 2,0 \% \text { e } 2,5 \% \text { ). }\end{array}$ & $\begin{array}{l}\text { Quando foram aplicadas misturas de } 0,5 \text { e } \\
1,0 \% \text {, a remoção média de DQO foi de } 81 \% \text {, } \\
\text { para o reator contínuo e } 86 \% \text { para o operado } \\
\text { em bateladas. Para Carbono Orgânico Dis- } \\
\text { solvido, a remoção média foi de } 79 \% \text { e } 49 \% \text {, } \\
\text { respectivamente. No período de operação } \\
\text { com } 2,0 \text { e } 2,5 \% \text {, as remoções de DQO foram } \\
\text { de } 85 \% \text { (contínuo) e } 90 \% \text { (bateladas). }\end{array}$ \\
\hline $\begin{array}{l}\text { FERREIRA, } \\
\text { J.A. et al } \\
\text { (2009) Uni- } \\
\text { versidade } \\
\text { Estadual de } \\
\text { Pernambuco }\end{array}$ & $\begin{array}{l}\text { Desempenho de reatores } \\
\text { UASB recebendo mistura } \\
\text { de lixiviado e esgoto. }\end{array}$ & $\begin{array}{l}\text { Foram operados dois reatores UASB (em pa- } \\
\text { ralelo) cada um com TDH médio de } 12 \text { horas. } \\
\text { Foram testados valores da relação lixiviado/ } \\
\text { esgoto de } 1,0 \% \text { (UASB1) e } 10,0 \% \text { (UASB2), e } \\
\text { media de 1,2 e } 3,4 \mathrm{~kg} \text { DQO m3. dia-1 } \text {, respecti- }^{-1} \text {, } \\
\text { vamente. Também foi testado stripping, antes } \\
\text { da alimentação do reator. }\end{array}$ & $\begin{array}{l}\text { A remoção de DQO no UASB foi de } 55 \% \text {, } \\
\text { e, no UASB2, } 45 \% \text {. No afluente bruto } \\
\text { submetido a stripping, houve remoção } \\
\text { de } 98 \% \text { do N-Amoniacal. }\end{array}$ \\
\hline $\begin{array}{l}\text { FERREIRA, } \\
\text { J.A. et } \\
\text { al (2009) } \\
\text { Universida- } \\
\text { de Estadual } \\
\text { do Rio de } \\
\text { Janeiro }\end{array}$ & $\begin{array}{l}\text { Influência da mistura } \\
\text { lixiviado e esgoto em lagoa } \\
\text { de estabilização e lagoa } \\
\text { aerada. }\end{array}$ & $\begin{array}{l}\text { Foram avaliados dois sistemas: a) lagoa } \\
\text { facultativa + lagoa de maturação; e, b) lagoa } \\
\text { aerada + lagoa de sedimentação. A lagoa } \\
\text { facultativa foi operada com TDH médio de } \\
6,61 \text { e } 15,2 \text { dias, e, a aerada, com } 3,6 ; 4,8 \text { e } \\
7,1 \text { dias. Foram testados valores de relação } \\
\text { lixiviado/esgoto de: } 0,2 \% ; 0,5 \% / 2,0 \% \text { e } 5,0 \% \text {. }\end{array}$ & $\begin{array}{l}\text { O sistema a), quando operado apenas } \\
\text { com esgoto, alcançou eficiência média } \\
\text { de } 71 \% \text { (remoção de DQO), e, quando } \\
\text { foi aplicado o lixiviado a eficiência } \\
\text { variou na faixa de } 42 \% \text { s } 51 \% \text {. No sis- } \\
\text { tema b), sem a aplicação do lixiviado } \\
\text { a remoção média de DQQ foi de } 82 \% \text {, } \\
\text { e, quando aplicado o lixiviado: de } 56 \% \\
\text { a } 72 \% \text {. }\end{array}$ \\
\hline
\end{tabular}

QUADRO 2 - Resumo de conclusões de algumas pesquisas sobre tratamento conjunto de lixiviado e esgoto desenvolvidas no programa PROSAB (2009) 
O tratamento químico (coagulantes e auxiliares) dificilmente promove remoção estável de DQO superior a $60 \%$, pois o lixiviado possui parcela significativa de componentes solúveis. Para se alcançar remoção de DQO em sistema de lodos ativados com alimentação contínua e remoção próxima a 70\%, o TDH teve de ser superior a 17 horas. O reator UASB, com TDH de 12 horas não tem condições de remover seguramente mais que 55\% da DQO de mistura afluente. O descarte de lixiviado em lagoa facultativa ou lagoa aerada provocou redução da eficiência de remoção de DQO na faixa de 10 a 29\%. Em nenhuma das pesquisas foram caracterizados os componentes do lixiviado referentes a DQO residual no efluente tratado.

\section{Ponderações gerais}

Para ilustrar as considerações sobre certos "critérios" usuais para as avaliações (autorizações para descarte de lixiviado em ETE), mais corriqueiramente efetuadas sobre "impactos" do descarte do lixiviado em ETEs, apresenta-se aqui, um exemplo hipotético.

Suponha-se um cenário em que uma cidade com população de 250.000 habitantes, gere 630 $\ell \mathrm{s}^{-1}\left(54.432 \mathrm{~m}^{3} \cdot\right.$ dia $\left.^{-1}\right)$ de esgoto, e $150 \mathrm{~m}^{3} \cdot \mathrm{dia}^{-1}$ de lixiviado, que será lançado na ETE em cujo projeto previa-se apenas o tratamento de esgoto sanitário, com eficiência (EF1) de 90\% de remoção de DQO. Para esse exemplo serão adotados os valores de DQO bruta de $650 \mathrm{mg} \cdot \ell^{-1}$, para o esgoto, e $15.000 \mathrm{mg} \cdot \ell^{-1}$, para o lixiviado.

Antes de se iniciar o descarte de lixiviado na ETE, a carga total de DQO lançada no corpo receptor seria, então de $3.538 \mathrm{~kg}$. dia-1, ou seja: $0,10 \times 54.432 \times 650 \times 10^{-3} \mathrm{~kg} \cdot \mathrm{dia}^{-1}$.

Nesse exemplo, o impacto do descarte do lixiviado na "qualidade" do efluente, fundamentado, será analisado de acordo com as estimativas e critérios mais comumente utilizados pelos profissionais encarregados dessa tarefa: balanço de massa fundamentado na DQO.

Serão destacadas duas alternativas para essa estimativa, sendo, a primeira (ALTERNATIVA 1) baseada na suposição que ocorrerá degradação da DQO do lixiviado, também de $90 \%$ e, a segunda (ALTERNATIVA 2) mais realista, e menos usada na prática atual, supor-se-á que cerca de 42\% (segundo LANGE et al - 2009) da DQO do lixiviado representa a fração de compostos recalcitrantes, portanto não degradados no sistema de tratamento.

Na Tabela 1, apresentam-se dados comparativos para três cenários.

Com base nesses dados, mormente quando se considera a ALTERNATIVA 1, "conclui-se" que os danos na eficiência da ETE seriam desprezíveis. Porém, ocorre o lançamento de carga adicional no corpo receptor; na ALTERNATIVA 1 isso corresponde a cerca de 6,4\%, e, na ALTERNATIVA 2, 26,7\%. Tomou-se como referência a carga

\begin{tabular}{|c|c|c|c|c|c|c|}
\hline CENÁRIO & $\begin{array}{c}\text { Vazão } \\
\mathrm{m}^{3} \cdot \text { dia }^{-1}\end{array}$ & $\begin{array}{l}\text { DQO Afluente } \\
\left(\mathrm{mg} \cdot \mathrm{l}^{-1}\right)\end{array}$ & $\begin{array}{l}\text { Carga Afluente } \\
\left(\mathbf{k g} \cdot \mathrm{dia}^{-1}\right)\end{array}$ & $\begin{array}{l}\text { Carga Efluente } \\
\left(\mathrm{kg} \cdot \mathrm{dia}^{-1}\right)\end{array}$ & $\begin{array}{l}\text { DQO Efluente } \\
\left(\mathrm{mg} \cdot \mathrm{l}^{-1}\right)\end{array}$ & $\begin{array}{l}\text { Eficiência Global } \\
\text { (DQO) (\%) }\end{array}$ \\
\hline \multicolumn{7}{|c|}{ Sem lançamento de lixiviado } \\
\hline Esgoto & 54.432 & & & & & \\
\hline Lixiviado & 0 & 650 & 35.381 & 3.538 & 65 & 90 \\
\hline Mistura & 0 & & & & & \\
\hline \multicolumn{7}{|c|}{ ALTERNATIVA 1} \\
\hline Esgoto & 54.432 & 650 & 35.381 & 3.538 & - & - \\
\hline Lixiviado & 150 & 15.000 & 2.250 & 225 & - & - \\
\hline Mistura & 54.582 & $689^{*}$ & 37.631 & 3.763 & 69 & 90 \\
\hline \multicolumn{7}{|l|}{ ALTERNATIVA 2} \\
\hline Esgoto & 54.432 & 650 & 35.381 & 3.538 & - & - \\
\hline Lixiviado & 150 & 15.000 & 2.250 & 945 & - & - \\
\hline Mistura & 54.582 & $689^{*}$ & 37.631 & 4.483 & 82 & 87,4 \\
\hline
\end{tabular}

*689, $44 \mathrm{mg} \cdot \ell^{-1}$, arredondado para: $689 \mathrm{mg} \cdot \ell^{-1}$. Valor usado como referência para cálculo da eficiência nas ALTERNATIVAS 1 e 2.

TABELA 1 - Comparações hipotéticas (cargas e eficiências) de diferentes cenários em uma ETE, com e sem descarte delixiviado. 
afluente de esgoto bruto.

Essas experimentações demonstram, categoricamente, que apenas considerar-se a eficiência do sistema como referência conduz a interpretações inconsistentes. Há aumento na carga lançada no corpo receptor. A isso se alia o fato de que seus componentes não são conhecidos. E o mais grave, não se conhece o quê causa essa sobrecarga.

Para o consultor desatento, o dano é pequeno e quase inexistente, porém, ele apenas focaliza-se no valor numérico da eficiência da ETE, e taxas de carregamento nas unidades que compõem o sistema.

O quê então foi "adicionado" ao efluente da ETE: substâncias húmicas, fúlvicas, lignina, subprodutos da degradação microbiana, fármacos, enzimas, "conservantes", metais, ...? Não se sabe.

Para complementar este tópico do texto, incluem-se algumas observações de diferentes pesquisadores.

A lignina é um produto polimérico natural que tem natureza aromática e estrutura bastante complexa, "altas concentrações de lignina, dificilmente são removidas por processos biológicos" (LEITÃO, R.C. - 1991).

LANGE, L.C. et al (2009) cita que a concentração de sulfatos e de sulfetos pode variar na faixa de 0 a $5.400 \mathrm{mg} \cdot \ell^{-1}$ e de 0 a $35 \mathrm{mg} \cdot \ell^{-1}$, em lixiviados de aterros brasileiros. É notório que tanto os sulfetos como os sulfatos podem estar associados a efeitos de corrosão (metálica e de concreto). Além disso, como os sulfatos são reduzidos em reatores anaeróbios, também pode haver dano ao processo biológico (o quê também ocorre no tratamento aeróbio).

A rede coletora, caso o lixiviado seja lançado na mesma, também pode sofrer danos de corrosão e mau odor (o limiar de risco de segurança, para sulfetos para o ser humano na atmosfera é de cerca de $\left.10 \mathrm{mg} \cdot \ell^{-1}\right)$. O sulfeto de hidrogênio estimula o desenvolvimento de bactérias que causam a desintegração do concreto; 1 a $10 \mathrm{mg} \cdot \ell^{-1}$ já são suficientes para tal (WRCF - 1968).

As substâncias húmicas são geradas em processos de decomposição de matéria orgânica, e sua estrutura depende do tipo de substrato e dos micro-organismos responsáveis por sua decomposição. Face a isso podem possuir composições químicas fortemente distintas. "Essa diferenciação influenciará nas reações químicas das mes- mas em meio aquoso, que dependem, dentre outros fatores, do caráter aromático ou alifático das moléculas húmicas envolvidas" (COSTA, C.A. - 1992).

Essas substâncias têm reflexo negativo na desinfecção com cloro, apresentam ação em processos corrosivos e podem produzir substâncias nocivas à saúde, propiciando a geração de compostos orgânicos halogenados (COSTA, C.A. 1992).

ARAUJO, R.A. (1985), cita vários inconvenientes provocado por substâncias húmicas, entre os quais: i) a intensificar processo de corrosão; (ii) potencização na formação de compostos danosos a saúde, quando reage com cloro usado na desinfecção; iii) servir como "proteção" de micro-organismos reduzindo o efeito da desinfecção; iv) ter a propriedade de gerar cor nas águas, etc.

SAPIA, F.M.A. e MORITA, D.M. - 2003, tecem ponderações que aqui são destacadas: a redução da concentração de um determinado poluente nas ETEs pode ser consequência de vários fenômenos, entre os quais a biodegradação, volatilização, retenção em sólidos biológicos (lodo, processos químicos, sedimentação, flotação, filtração, etc). Contudo, dependendo do contaminante, parcela significativa pode estar presente no efluente, na forma de subprodutos indesejáveis. Assim, os efluentes não domésticos devem obedecer critérios rigorosos quanto ao seu lançamento em sistemas públicos.

\section{Resolução conama 430, de 13 de maio de 2011}

Até o presente, no Brasil, aparentemente, não se tem dada a devida atenção para a problemática decorrente do descarte de lixiviados em ETEs. Há restrições e recomendações, contudo ainda não prevalece consenso sobre o tema.

Segundo Sapia, F.M.A. e Morita, D.M. (2003), descarte de lixiviados e de outros efluentes potencialmente danosos é abordado na RESOLUÇÃO CONAMA № 430 (13/5/11), porém, segundo o autor deste texto, no que concerne a lixiviado, o enfoque poderia ser mais específico e direcionado às responsabilidades dos profissionais e entidades que optarem pelo descarte de lixiviado em ETEs.

Na RESOLUÇÃO CONAMA № 430 de 13 de maio de 2011 (BRASIL - Ministério do Meio Ambiente - CONAMA - 2011) há tópicos em que se nota a preocupação com o lançamento de efluentes (não sanitários) em redes coletoras de esgoto, 
mesmo com tratamento, que direta ou indiretamente podem ser aplicados à problemática do descarte de lixiviados em ETEs, a saber (grifos do autor do presente texto).

CAPÍTULO II, Seção I, Art. $7^{\circ}$, § 3․ "O empreendedor, no processo de licenciamento, informará aos órgãos ambientais as substâncias que poderão estar contidas no efluente gerado, entre aquelas listadas ou não na Resolução CONAMA $n^{\circ} 357$, de 2005, para padrões de qualidade da água, sob pena de suspensão, ou cancelamento da licença expedida".

CAPÍTULO II, Seção I, Art. 8, § 8․ "É vedado, nos efluentes, o lançamento de Poluentes Orgânicos Persistentes - POPs, observada a legislação em vigor".

CAPÍTULO II, Seção II, Art. 18․ "O efluente não deverá causar ou possuir potencial para causar efeitos tóxicos aos organismos aquáticos no corpo receptor com os critérios de ecotoxicidade estabelecidos pelo órgão governamental".

CAPÍTULO II, Seção II, Art. $21^{\circ}$, § 2․ "No caso de sistemas de tratamento de esgotos sanitários que recebem lixiviados de aterros sanitários, o órgão ambiental competente deverá indicar quais os parâmetros da Tabela I, do Art. 16, § II desta Resolução deverão ser atendidos e monitorados não sendo exigível o padrão de nitrogênio amoniacal total".

CAPÍTULO II, Seção II, Art. 23, § 1. "Os testes de ecotoxicidade em efluentes de sistemas de tratamento de esgotos sanitários têm como objetivo subsidiar ações de gestão da bacia contribuinte aos referidos sistemas, indicando a necessidade de controle nas fontes geradoras de efluentes com características potencialmente tóxicas ao corpo receptor".

Note-se que há subsídios para que os órgãos responsáveis por controle da qualidade ambiental atuem com mais rigor em ETEs que recebem lixiviados, e sobre a qualidade do projeto e da operação dessas ETEs.

Contudo, o $§ 2^{\circ}$, do artigo 21 (Seção II, Capítulo II) - a menos que haja interpretação imprecisa por parte do autor deste texto - favorece àquelas ETEs que recebem lixiviados, pois, claramente expressa "não sendo exigível o padrão de nitrogênio amoniacal”. Ou seja, enquanto obriga-se a ETEs que não recebem lixiviado a respeitar rigorosamente os padrões de emissão/qualidade relacionados ao Nitrogênio, libera-se as ETEs que não são submetidas a esse procedimento!
É de se esperar, portanto, que em futuras revisões dessa RESOLUÇÃO, a referida colocação seja objeto de adequação.

\section{Conclusões e recomendações}

O descarte do lixiviado de aterros sanitários em ETEs pode ser uma alternativa para "destino" desses resíduos, contudo, tanto a avaliação preliminar do projeto da ETE, para autorizar esse descarte, como o monitoramento da ETE têm de ser efetuados com base em critérios mais rigorosos do que aqueles que vem sendo empregados. Geralmente a autorização e o monitoramento dessas ETEs têm ocorrido apenas com base em ponderações superficiais.

Decisões baseadas apenas em análises de DQO, DBO, Nitrogênio, Fósforo e Sólidos, e fundamentadas em "balanços de massa", não oferecem base segura para tomada de decisões. Tanto os resultados de DQO como os de DBO podem se afastar da realidade. Para se proceder aos ensaios de DBO é necessário que se use inóculo (semente) previamente preparado com o respectivo substrato. $\mathrm{Na}$ DQO, por sua vez, podem não terem sido incluídos (quantificados) diversos componentes do lixiviado. Destaque-se que, a fração de componentes refratários ao tratamento, que Lange et al (2009) denominam DQO "inerte" pode não estar sendo ponderada adequadamente.

Não se podem utilizar os mesmos modelos e cinética dos processos biológicos de degradação do esgoto sanitário para os componentes do lixiviado. Tem-se de estudar a degradação biológica do lixiviado baseada na cinética pertinente a esses resíduos, incluindo-se estimativa relacionada com a DQO "inerte" e coeficientes cinéticos específicos.

Para pesquisas e para monitoramento das ETEs que recebem lixiviado, determinações de DBO e DQO e Nitrogênio, não bastam para caracterizar o afluente e o efluente. Há necessidade de se utilizar recursos técnico/científicos para qualificações adicionais, entre os quais podem-se citar: Difratograma de Raio X, Cromatografia Líquida, Espectografia (no Infravermelho e no UV Visível), Cromatografia Gasosa Acoplada a Espectrografia de Massas (LANGE et al 2009), Absorção de Radiação Ultravioleta, Espectroscopia (fluorescência) (YUNUS et al 2011). Somem-se a isso, estudos de toxicidade e avaliação de componentes de diferentes massas moleculares (Ultra-Filtração em Membranas e Cromatografia em Gel). 
Com base nas pesquisas enumeradas neste texto, relacionadas ao tratamento do lixiviado (sem mistura com esgoto), conclui-se que o tempo necessário para degradação de componentes do lixiviado é muito maior do que o tempo em que esse resíduo permanece em ETEs, projetadas com parâmetros usuais. Além disso, mesmo sob condições em que há adaptação dos micro-organismos, sempre há valor residual significativo de DQO (cujos "causadores" não são caracterizados). Essa constatação demonstra que na ETE ocorre a diluição do lixiviado e apenas degradação parcial de seus componentes.

De maneira geral, os pesquisadores constatam que o nível de toxicidade dos efluentes do tratamento conjunto é menor do que o do lixiviado ou mistura lixiviado-esgoto afluente às ETEs. Isso pode levar à inferência de que, a maior parte desse decaimento pode decorrer da diluição, que geralmente ultrapassa 100 vezes (se a relação lixiviado/esgoto for menor que $1 \%$ ).

Em todos os cenários, quando se descarta lixiviado em ETEs há aumento da carga lançada no corpo receptor, mesmo que a eficiência da ETE se mantenha (tomando-se como referência, a DQO da mistura). Porém, sempre se detecta algum declínio na eficiência da ETE, quando ela passa a receber o descarte de lixiviados.

Em adição ao que foi abordado nessas ponderações, outros problemas são citados nos textos levantados, como consequência do descarte de lixiviados em ETEs:

- Redução de sedimentabilidade de flocos, quando se trata de sistemas de lodos ativados.

- Dificuldade para ajuste/ dosagem de produtos químicos.

- Surgimento de fenômenos de geração de escuma, cor e corrosão.

- Aumento das concentrações de metal no lodo.

- Aumento da produção de lodo e de consumo de energia elétrica em sistemas de lodos ativados.

- Aumento da demanda de produtos químicos.

Como conclusão geral tem-se que: i) Os critérios de avaliação para justificar o lançamento de lixiviado gerado em aterros sanitários em ETEs têm de ser aprimorados. Não há segurança efetiva de critérios baseados apenas nas análises de DBO, DQO, N, P e metais; ii) Parte dos componentes do lixiviado é tratada ou removida em ETEs, porém, parte significativa é apenas diluída; iii) Há problemas decorrentes na ETE: corrosão, odor elevação de cor, dificuldade para controle de dosagem e aumento no consumo de produtos químicos; iv) Há necessidade de se aumentar o número de variáveis monitoradas no afluente da ETE, no lixiviado e no efluente da ETE; v) considerar eficiência baseada em valores de DBO, DQO, $\mathrm{N}$ e P e sólidos não oferece garantia sobre os componentes presentes nos efluentes da ETE; vi) $\mathrm{O}$ descarte de lixiviado de aterros sanitários em ETEs não garante que esse lixiviado seja efetiva e completamente tratado.

A Resolução CONAMA 357 de 13 de maio de 2011, no que concerne aos enfoques sobre ETEs que recebem lixiviado, deve ser objeto de revisão e complementação; e, as exigências específicas dos órgãos de fiscalização/monitoramento dessas ETEs devem ser revisadas e efetuadas com maior vigor.

\section{Referências bibliográficas}

AQUINO, S.F. de - Caracterização da DQO de Efluente de Sistemas de Tratamento Biológico. Engenharia Sanitária e Ambiental - ABES, Rio de Janeiro - RJ, Vol. 8, № 3, Jul./Set., 2003, pp. 135144. ARAÚJO, R.A. - Remoção de Substâncias Húmicas Através de Floculação com Sulfato de Alumínio, Cloreto Férrico e Polímeros Naturais e Sintéticos. Dissertação (Mestrado), Escola de Engenharia de São Carlos - USP, São Carlos-SP, 1985, p. 251.

BLACK, A.P. \& RUSSEL, F.C. - Chemical Characteristics of Fulvic Acids. Journal AWWA, July, 1963, p. 897-912.

BOCCHIGLIERI, M.M. - O Lixiviado de Aterros Sanitários em Estações de Tratamento dos Sistemas Públicos de Esgotos. Tese (Doutorado), Faculdade de Saúde Pública - USP São Paulo - SP, 2010, 255 p.

BRASIL - Ministério do Meio Ambiente, CONAMA - Conselho Nacional do Meio Ambiente, RESOLUÇÃO № 430, de 13 de maio de 2011. “Condições e Padrões de Lançamento de Efluentes, Complementa e Altera a RESOLUÇÃO № 357, de 17 de março de 2005".

CASTILHOS, A.B.; FERNANDES, F.; LANGE, L.C.; LOPES, D.D.; COSTA, R.H.R.; SILVA, S.M.; MARTINS, L.L.; FERREIRA, C.F.A. e MORAVIA, N.G. Tratamento de Lixiviado de Aterro Sanitário em 
Sistema de Lagoas, in GOMES, L.P. (2009) Resíduos Sólidos: Estudos de Caracterização e Tratabilidade de Lixiviados de Aterros Sanitários para as Condições Brasileiras. PROSAB, ABES. ISBN 978-85-7022-163-6. Rio de Janeiro - RJ., 2009, $358 \mathrm{p}$.

CLARETO, C. - Tratamento Biológico de Líquidos Percolados em Aterros Sanitários Utilizando Reator Anaeróbico Compartimentado. Mestrado (Dissertação), Escola de Engenharia de São Carlos - USP São Carlos - SP, 1997, 280 p.

COSTA, C.A. - Coagulação de Substâncias Húmicas por Sulfato de Alumínio. Tese (Doutorado), Escola de Engenharia de São Carlos - USP, São Carlos - SP, 1992, 332 p.

FERREIRA, J.A.; CANTANHEDE, A.L.G.; LEITE, V.D.; BILA, D.M.; CAMPOS, J.C.; YOKOYAMA, L.; FIGUEIREDO, I.C.; MANNARINO, C.F.; SANTOS, A.S.; FRANCO, R.S.O.; LOPES, W.S. e SOUZA, J.T. - Tratamento Combinado de Lixiviados de Aterros de Resíduos Sólidos Urbanos com Esgoto Sanitário, in GOMES, L.P. (coord) (2009) - Resíduos Sólidos: Estudos de Caracterização e Tratabilidade de Lixiviados de Aterros Sanitários para as Condições Brasileiras, ISBN 978-85-7022-163-6, PROSAB - ABES, Rio de Janeiro - RJ, 2009, 360 p.

GOMES, L.P. Coord. - Resíduos Sólidos: Estudos de Caracterização e Tratabilidade de Lixiviados de Aterros Sanitários para as Condições Brasileiras, ISBN 978-85-7022-163-6, PROSAB - ABES, Rio de Janeiro - RJ, 2009, 360 p.

GOMES, L.P.; LANGE, L.C.; AMORIM, A.; MIRANDA, A.S.; FERREIRA, C.F.A.; MORAVIA, W.G. e GOMES, L.A. - Aplicação de Tratamentos Biológicos Anaeróbios para Lixiviados de Resíduos Sólidos Urbanos, in GOMES, L.P. (Coord.) (2009) Resíduos Sólidos: Estudos de Caracterização e Tratabilidade de Lixiviados de Aterros Sanitários para as Condições Brasileiras, ISBN 978-85-7022-163-6, PROSAB - ABES, Rio de Janeiro - RJ, 2009, 360 p.

LANGE, L.C. e AMARAL, M.C.S. - Geração e Características do Lixiviado, in GOMES, L.P. (Coord.) (2009) Resíduos Sólidos: Estudos de Caracterização e Tratabilidade de Lixiviados de Aterros Sanitários para as Condições Brasileiras, ISBN
978-85-7022-163-6, PROSAB - ABES, Rio de Janeiro - RJ, 2009, 360 p.

LEITÃO, R.C. - Avaliação do Processo Eletrolítico para Remoção de Cor Devida a Lignina. Dissertação (Mestrado), Escola de Engenharia de São Carlos - SP, 1991, p. 178.

LOPES, D.D.; SILVA, S.M.C.P.; FERNANDES, F.; AMORIM, A.K.B.; HASSAKA, A.L.; MARINGONDA, A.; FREITAS, B.O.; BRITES, E.C.F.; TRENNEPOHL, F.G. e BATISTA, G.A. - Tratamento Biológico de Lixiviado com Remoção de $\mathrm{N}$ : Sistema de Lodos Ativados, in GOMES, L.P. (Coord.) (2009) Resíduos Sólidos: Estudos de Caracterização e Tratabilidade de Lixiviados de Aterros Sanitários para as Condições Brasileiras, ISBN 978-85-7022-163-6, PROSAB ABES, Rio de Janeiro - RJ, 2009, 360 p.

OZKAYA, B.; DEMIR, A. \& BILIGI, M.S. - Soluble Substances Concentrations in Leachate from Field Scale MSW Test Cells - Journal of Hazardors Matinals A 134, 2006, 19-26.

SAPIA, P.M.A. e MORITA, D.M. - Critérios de Recebimento de Efluentes não Domésticos em Sistemas Públicos de Esgotos: Uma Análise Crítica. Engenharia Sanitária e Ambiental - ABES, Rio de Janeiro - RJ, Vol. 8, № 3, 2003, p. 145-156.

WPCF - WPCF Manual of Practice № 3 - Regulation of Sewer Use. Water Pollution Control Federation. Washington D.C., 1968, 41 p.

YUNUS, A.; SMALLMAN, D.J.; STRINAFELLOW, A.; BEAVEN, R. e POWRIE, W. - Characteristics of the Recalcitrant Organic Compounds in Leachates Formed During the Anaerobic Biodegradation of Waste. Water Science \& Technology: IWA - London, Vol. 64, № 2, 2011, pp. 311-319.

\section{SOBRE O AUTOR}

José Roberto Campos

Professor titular na área de Hidráulica e Saneamento, no Departamento de Hidráulica e Saneamento da Escola de Engenharia de São Carlos, USP. 